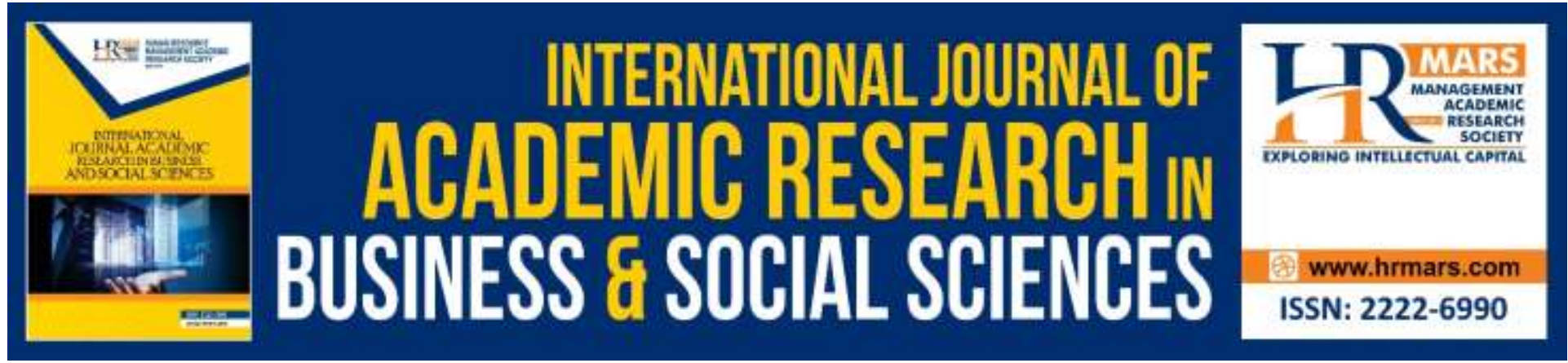

\title{
Generation Y's Brand Loyalty for Smartphone in Malaysia
}

\author{
N. H. Marmaya, N. A. Razak, N. E. Alias, R. A. Karim, J. R. Saari, H. \\ Borhan, W. L. Koe, S. M. Salim
}

To Link this Article: http://dx.doi.org/10.6007/IJARBSS/v9-i10/6460

DOI: 10.6007/IJARBSS/v9-i10/6460

Received: 10 September 2019, Revised: 25 September 2019, Accepted: 12 October 2019

Published Online: 28 October 2019

In-Text Citation: (Marmaya et al., 2019)

To Cite this Article: Marmaya, N. H., Razak, N. A., Alias, N. E., Karim, R. A., Saari, J. R., Borhan, H., ... Salim, S. M. (2019). Generation Y's Brand Loyalty for Smartphone in Malaysia. International Journal of Academic Research in Business and Social Sciences, 9(10), 105-117.

Copyright: (C) 2019 The Author(s)

Published by Human Resource Management Academic Research Society (www.hrmars.com)

This article is published under the Creative Commons Attribution (CC BY 4.0) license. Anyone may reproduce, distribute, translate and create derivative works of this article (for both commercial and non-commercial purposes), subject to full attribution to the original publication and authors. The full terms of this license may be seen

at: http://creativecommons.org/licences/by/4.0/legalcode

Vol. 9, No. 10, 2019, Pg. 105 - 117

Full Terms \& Conditions of access and use can be found at http://hrmars.com/index.php/pages/detail/publication-ethics 


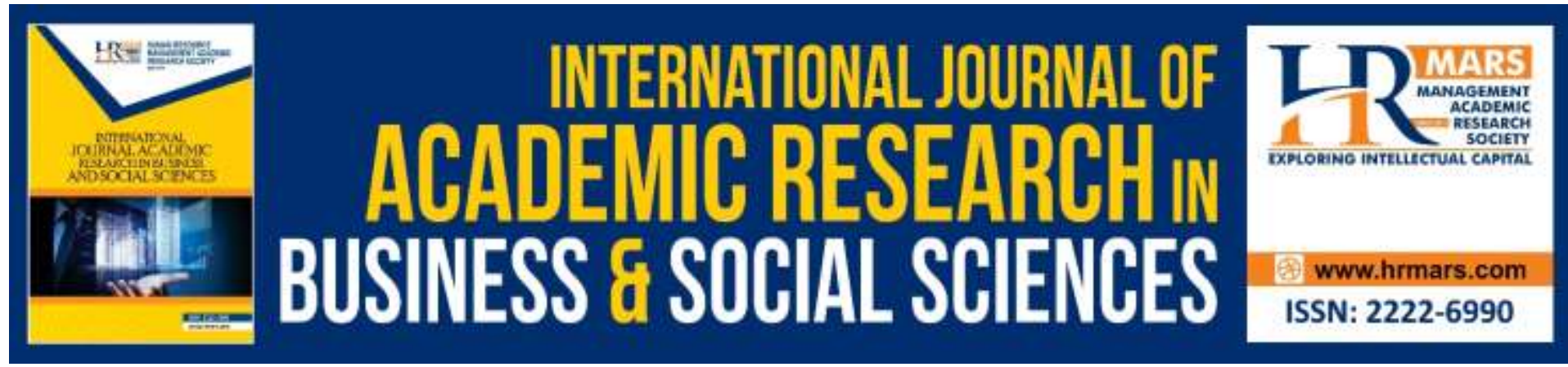

\title{
Generation Y's Brand Loyalty for Smartphone in Malaysia
}

\author{
N. H. Marmaya, N. A. Razak, N. E. Alias, R. A. Karim, J. R. \\ Saari, H. Borhan, W. L. Koe, S. M. Salim \\ Faculty of Business and Management, Universiti Teknologi MARA, Melaka, Malaysia
}

\begin{abstract}
The study is conducted to investigate factors that influenced Malaysia's Generation $Y^{\prime}$ brand loyalty for smartphone Malaysia. A quantitative method was adopted in this study and responses were obtained from 152 Generation $Y$ in Malaysia. Using SPSS 20, the results showed that a significant relationship between brand image, trust and customer satisfaction towards smartphone brand loyalty among Generation $\mathrm{Y}$, while promotion did not play a significant role to Smartphone brand loyalty among Generation $Y$ in Malaysia. This study adopts a cross-sectional research design and examines the opinions of consumers at only one point in time. Future research should attempt to reach larger groups of respondents to validate the theoretical linkage tested in the present study. Secondly, this results in a relatively small size (152), compared with the population size. This also might affect the representative of the outcomes. There are several more suggestions to further extend the current model. First, the research model can be tested in different group of customer and investigates if people with different background may assess different brand loyalty to buy Smartphone in different ways. Longitudinal research design should be done for a better result. The results of this study provide several important theoretical and practical implications for Smartphone brand management.
\end{abstract}

Keyword: Generation Y, Brand Image, Trust, Customer Satisfaction, Promotion and Brand Loyalty

\section{Introduction}

The smartphone market has been growing rapidly in several countries as this industry becomes important market in all country around the world. The used of smartphone really important and achieved high demand as its help us in doing thing on our daily life. It would also can boost on profit of a business by helping the marketer or the seller to market their product in any type of media such as application that present throughout the smartphone itself. It becomes a major need for all people in many range of ages which may include the teenager nowadays. It becomes a trends for each of the individual to have a smartphone even the brand of the smartphone also would influence the people. In this modern technology, the most smartphone brand that every people want to purchaseare Apple, Samsung, Huawei and many other global brand of smartphone. These global brand are competing each other to grab 
a greater market share around the world and always comes out with a new idea of the product where they innovate and launced a new model of their product. Raval, R. \& Trivedi, R. (2018) revealed seven major components like Product Features, Price, Brand Image, Promotional Offers, Service center, Brand Image and Smartphone Looks which influence consumer Purchase Intentions towards smartphone. The company of smartphone would makes many type of strategy of marketing where to attract a lots of customer to buy their product and also can maintain those customer who buy their product, which means the loyal customer would choose the brand when comes on purchasing a smartphone. Brand loyalty is a deep commitment to rebuy or repatronize as a consistent choice of products or services in the future, resulting in the same brand of repetition or the purchase of the same brand, despite the influence and marketing efforts potentially leading to shifting the switch. There are many factor that could influenced brand loyalty towards brand of smartphone. Brand image is one of the most complex factors it strongly and significantly influences consumer preference to present his or her image. Based on other researcher, brand image is an important factor that could influence a people to loyal towards a brand. Chen and Huang (2013) explained the definition of trust as believing that the information obtained is accurate, transparent and reliable. Trust is always associated with a relationship involved, either with other parties or other things (Greenwood \& Van Buren III, 2010). According to Anderson and Srinivasan (2003) who confirmed that satisfaction has a relationship with brand loyalty. The researcher wished to study on this issue to seek out out on how brand image influence brands loyalty. Studies showed that attractiveness of brand indirectly affects brand loyalty and other people use product to boost personality (Kinuthia et al., 2012). Satisfaction will increase loyalty once brand loyalty is measured in an exceedingly range of consecutive purchases of an equivalent brand (LaBarbera and Mazursky, 1983). Promotion is a vital component to form promoting methods and use to speak with customers with regard to product offerings and also encourage the acquisition of product and services (Wong \& Sidek, 2008). As nowadays becomes more modern and achieve globalization world, the choice and needs of the customer also become variety, hence, this makes the global brands always comes out with a new product and model that can capture and grab heart and fully needs the desire of their target customer. Promotional results will have an impact on switching behaviour (Sun, 2005). Kahn and Louie (1990) explained that promotional activities can cause consumers to change their choices on unfamiliar brands. Some studies provide tools or models that can determine the duration of promotion during the transition period for customers switching do different brands (Lin \& Lin, 2008). According to Esfahani and Jafarzadeh (2012), the variety seekers who prefer to switch brand, these consumers are more likely to be sensitive to promotions because they stimulate brand switching.

A number of researcher have examined the relationship between brand image, satisfaction and loyalty in the retail store (eg., Koo, 2003; Chang \& Tu, 2005; Martenson, 2007) and service industry (eg., Lewis \& Soureli, 2006), but still there are a limited number of studies focusing on product markets specifically among Generation $Y$. The rationale for focusing on smart phone study among Generation $Y$ is because Malaysians change their mobile phones more frequently than other technology devices (Ling, Goyindan, and Radhakrishnan, 2018). Additionally, Generation $Y$ is known as a technology savvy generation, consumption orientations, values of being the trendsetters and establishments towards brand consciousness. It is interesting to note that most Generation $Y$ members are born to parents with stable financial background and groomed in a multicultural and technology-rich 
contextual environment. The contextual environment has profound influences in their upbringing, their life style, and their personality as carefree, fun-loving, and risk-taking individuals (Marmaya et al., 2019).Therefore, the main objective of this study is to find out the relationship between brand image, trust, customer satisfaction and promotiontowards smart phone brand loyalty among Generation Y consumers in Malaysia. Hence, this study was conducted to determined whether the relationship between these variables were significant or not.

\section{Literature Review \\ Brand Image towards Brand Loyalty}

Brand image is that the perception of consumers regarding a few specific brand. Image of the brand tend to be changes over time. brand image is created within the minds of consumers primarily based upon the expertise and interaction of the purchasers with the brand, interactions will present itself in several ways that and not essentially solely the shopping for or exploitation of the merchandise or service. Moreover, the brand image will be strong by implement the employment of brand communication like packaging, advertising, creating the merchandise through public where it's unfold through word of mouth and different promotional tools. This image incorporates not solely the useful properties however also emotional and symbolic concerns (Tsai-Yuan \& Chang, 2013). Every organization makes a full efforts to create a powerful brand image as once the corporate have a stable and robust and powerful image, it's terribly useful to achieved the motives and objectives of a business. this could be seen on international brand smartphone like Apple, as once heard on this brand, the individuals perception on this brand are affected and have a top quality brand. This strong image of the brand will offer many edges that are it becomes easier to introduce new merchandise among a brand name, extra profits within the sort of new customers are attracted towards the merchandise or service and it helps increasing the trust level of existing customers. Brand image is one in all the foremost complicated factors and it affects loyalty in 2 ways; 1st is shopper favor to present his own image and also the second is individuals tend to classify themselves into completely different social classes that are analysis of objectives and values in numerous teams as compared with consumers' own values and objective as they meet similar objectives and values (Kuusik, 2007). Prestigious brand image attracts shoppers to get the brand and trigger them to repetitive buying and scale back in value doesn't have an effect on their change behavior and it's important for the brand having minor physical variations take competitive advantage (Wong \& Sidek, 2008). Brand image verify the sale of a product and it's important because it is aggregating views and beliefs related to a specific brand. The worth and character of the brand are represented through its image and ultimately it reflects the core values of the organization mirrored. When the brand expand on the market, usually consumer making their purchasing decision based on the brand image, rather than the product itself. For example, people still buying iPhones even there is a case which is Apple's bumpy battery cases in 2016, this cases worsen the reputation of sales of Apple but still people want to buy it as they have this perception where every individual should have at least one of the product from Apple brand. This shows how strong brand image of Apple are. According to Ogilvy \& Mather, the strong brand image can build the customer loyalty (Andreani et al., 2012). Loyal customer will recommend particular brand to other people and it cannot be influenced by competitor (Andreani et al., 2012). Hence, the hypothesis is : 
$\mathrm{H} 1$ : There is a relationship between brand image and brand loyalty

\section{Trust towards Brand Loyalty}

Trust is one of the factor that really important that could give impacts on brand loyalty. Individual would not purchase the brand and stay loyal when they are not in the position of trust towards the brand. In other words, no trust no loyalty towards the brand. previous study found that trust is the most important factor that could give impacts and influenced on brand loyalty (Singh, 2016). Customer who are loyal have willingness to pay more for the product due to its attractiveness features, uniqueness, high perceived quality that other brand don't provide to them. Previous study found that trust involve consumer commitment particularly within the scenario high involvement especially in product or service. The researcher conjointly declared that brand trust would offer impacts on loyalty (Li \& Chaipoopirutana, 2014). Trust from the partner also might additionally provide influence and also help establish and build loyalty. The past studies show that trust is extremely essential for the event the development loyalty (Chaudhuri and Holbrook, 2001). Customers trust in brand relies on positive beliefs relating to the expectations of the customers in a product or service. The motivation of the buyer truly depends on the qualifications set by the consumer to approach the real purpose and it's explicit as brand trust. (Ramiz, Qasim, Rizwan, Aslam, \& Khurshid, 2014). Trust is an important factor to develop marketing relationships and it retains when one party has confidence in an exchange and stated that trust and satisfaction are conceptually connected (Farhanullah \& Adeeba, 2013). Hence, the hypothesis is :

$\mathrm{H} 2$ : There is a positive relationship between trust and brand loyalty.

\section{Customer Satisfaction towards Brand Loyalty}

Customer satisfaction is the term that usually utilized in promoting. it always want to measure on how the merchandise and services that offered by the company fulfil or meet the client expectation. Variety of empirical studies show that customer satisfaction plays a really necessary role in developing repurchase behavior. Satisfaction will increase loyalty once brand loyalty is measured in a variety of sequential purchases of constant brand (LaBarbera and Mazursky, 1983). Customer satisfaction incorporates a strong relationship with brand loyalty. Moreover, there are different researcher state that customer satisfaction couldn't be clearly achieved without loyalty. When analysis of various factors as well as brand loyalty, several researchers found a positive relationship between customer satisfaction and brand loyalty (Li \& Chaipoopirutana, 2014). A study by Ross Beard (2014), applied and conduct survey of two hundred senior marketing managers found that $71 \%$ of them found that a customer satisfaction metric is extremely helpful in managing and monitoring their business. This could be conclude each business that need to be conduct should consider on customer satisfaction in order that it can helps on increase the profit of the company, this could also include on mobile phone industry. Each brand of smart phone that need to be introduce within the market should be initially creating an investigation wherever demand required to satisfied their target customer. Bontis et al. (2007) conducted the analysis and found that customer satisfaction improves reputation within the services markets. Reputation partially intervene the connection between satisfaction and loyalty and the relationship between satisfaction and recommendation. Hence, it is postulated that :

H3: There is a positive relationship between customer satisfaction and brand loyalty. 


\section{Promotion towards Brand Loyalty}

Advertisement is one amongst the promotion tools that is incurred cost however if it lasted for extended period, it doesn't involved too much cost. Brand awareness change the customer to spot one brand among many. Once a customer have a data relating to international brand it becomes a significant advantage wherever it extremely useful on customer getting decision (Doostar, Asil, \& Behrang, 2013). The customer might establish that the foremost most popular brand with sensible quality to be purchase after they discovered of knowledge relating to the brand. Promotion is one amongst the marketing mix elements and it's a source of communication that creates awareness concerning the merchandise and brand to customer. Promotion includes the employment of advertising, commercial, personal commerce and promotion. Advertising could be a non-personal presentation of information in mass media about a product, brand, company or store. It might provide great impacts on consumer images, beliefs and attitudes towards products and brands and in turn, influences their purchase behaviour (Evans et al, 1996). Advertisement extremely useful in many ways where it will establish ideas or perceptions into client minds, and also help on to differentiate one brand with other brand. Hence, once the company have a decent advertisement it have chance to draw in a lot of customer in which cause brand loyalty.

Moreover, once the company apply on effective communication to push on their brand, it will persuade and encourage the target client to have faith in and later it might flip them to require action on getting the product. Once this happened, this could change the target client initially into loyal client towards the brand. However, the success will solely be achieved once the marketer have planned a good promotion strategy. Promotion tools largely utilized by organization to form public relation activities (Ronaldo \& Atik, 2015). It also declared that promotion may be a key role in determining market success. according to the investigator, promotion is a very important component to form promoting strategies and use to speak with customers with regard to product offerings and additionally encourage the acquisition of product and services (Wong \& Sidek, 2008). Promotion particularly in sort of a well-targeted publicity not only create less price sensitive however also create loyal to the brand, what is more, it changes the information, behavior, and perspective of customers towards the brand. (Mise, Nair, Odera, \& Ogutu, 2013).

Hence, the hypothesis is: $\mathrm{H} 4$ : There's a relationship between promotion and brand loyalty

\section{Research Methodology Measurement}

The measurements are developed based on extensive reviews of past studies. The survey is divided into Section A is demographic profile, Section B is brand loyalty (Deari \& Balla, 2013), Section C is brand image (Tee, Behrooz \& Benjamin, 2013), Section D is trust (Chaudhuri and Holbrook, 2001), Section E is customer satisfaction (Bennett et al., 2007) and section $F$ is promotion (Czerniawski \& Maloney, 1999). The survey is measured using the five-point Likert scale (i.e. $1=$ strongly disagree and $5=$ strongly agree). A pre-test study is carried out using 50 Generation $Y$ undergraduate students from a public university. From this initial pretest, several questions are rephrased to improve the instrument's readability. 


\section{Sample}

The present study distributes a total of 200 questionnaires. The collected responses are later screened and examined for incomplete responses and credibility. This initial procedure has resulted in the removal of 48 incomplete or unreliable responses (i.e. out of 200), thus leaving a total of 152 usable responses throughout the three regional locations (Kuala Lumpur, Melaka and Sabah). The process of data analysis begins after all data is obtained from the respondents. The Statistical Package for Social Science (SPSS) for Windows was used to analyse the data and obtain answers for the research questions.

\section{Results}

From the total of 152 respondentsmajority of the survey respondents are from female population $(75.7 \%)$ and another $24.3 \%$ are from male population with about $80.9 \%$ of the respondents are at the age of 25 and below while another $19.1 \%$ are from the age 26 to 35 years old. Most of the respondents are from Selangor (48\%) whereas $28.3 \%$ are from Sabah and $23.7 \%$ from Melaka. About $79.6 \%$ of the respondents are majoring in bachelor degree, followed by majoring in Diploma (13.8\%), Master (0.7\%) and lastly the PhD holder carried out only $1.3 \%$.Based on this survey population in these 3 states, mostly answered by students $(69.1 \%)$, followed by the respondent who are working in private sector $(15.8 \%)$, in government sector (11.2\%) and lastly self -employed (3.9\%), hence, the monthly income or allowance that received the highest is less than RM500 (44.1\%) and the lowest income received is more than $\mathrm{RM} 2500$ (7.2\%). Most of the respondents are using Apple (36.2\%) and least brand of smartphone is Oppo (10.5\%).

\section{Reliability Analysis}

The reliability coefficient of factor structures is measured using the Cronbach's alpha. From table 1, the coefficient alpha values for the five constructs range from 0.76 to 0.95 , demonstrating good internal consistency and strong reliability of each dimension (Gerbing, D. W., \& Hunter, J. E., 1987).

Table 1: Results of Reliability Analysis

\begin{tabular}{|l|c|c|c|}
\hline & No. of Items & Cronbach's Alpha & $\begin{array}{c}\text { Internal } \\
\text { Consistency }\end{array}$ \\
\hline Brand Loyalty & 8 & 0.764 & Acceptable \\
\hline Brand Image & 6 & 0.884 & Good \\
\hline Trust & 6 & 0.901 & Very Good \\
\hline Customer Satisfaction & 7 & 0.956 & Very Good \\
\hline Promotion & 6 & 0.877 & Good \\
\hline
\end{tabular}

\section{Multiple Regression Analysis}

Multiple Regression is an extension of bivariate correlation is used to test the hypotheses. The result of regression is an equation that represents the relationship between brand image, trust, customer satisfaction and promotion towards brand loyalty. The table below shows the result of regression analysis of four independent variables; brand image, trust, customer satisfaction and promotion. 
Table 2: Results of Regression Analysis

\begin{tabular}{|l|l|l|l|}
\hline \multirow{2}{*}{ Model } & $\begin{array}{l}\text { Standardized } \\
\text { Coefficients }\end{array}$ & \multirow{2}{*}{ T } & \multirow{2}{*}{ Sig } \\
\cline { 2 - 3 } & Beta & \\
\hline (Constant) & & 2.883 & .000 \\
\hline Brand Image & .409 & 5.255 & .000 \\
\hline Trust & .155 & 1.416 & .029 \\
\hline Customer Satisfaction & .117 & 1.109 & .041 \\
\hline Promotion & .139 & 1.490 & .099 \\
\hline F-value & 39.466 & & \\
\hline Sig. & .000 & \multicolumn{2}{|l}{} \\
\hline Adjusted $R^{2}$ & .505 & & \\
\hline$R^{2}$ & .518 & & \\
\hline
\end{tabular}

As shown in table $2, R^{2}$ indicates the percentage variance in the dependent variable that is explained by the variation in the independent variables. The $R^{2}$ is 0.518 which means that all the variables (brand image, trust, customer satisfaction and promotion) explains $51.8 \%$ of the variance in brand loyalty. $48.2 \%$ of dependent variable is explained by other variable.Table 2 , shows the results of the hypotheses relationships. The analysis suggests a strong support on our three posited hypotheses (i.e. $\mathrm{H} 1, \mathrm{H} 2$ and $\mathrm{H} 3$ ) but not hypothesis 4 .

\section{Discussion and Conclusion}

This study discovers a significant relationship between brand image, trust and customer satisfaction towards brand loyalty. The results are supported by previous findings, eg.,Khundyz, Z. (2018) , Kansra and Kumar (2012) and Malik, Ghafoor \& Iqbal (2012). It has shown that positive effect of brand image of smart phone on customer loyalty among Generation $Y$ in Malaysia. Good brand image would help and prevent the customer to switch to other brand. When the smartphone has a strong brand image, it could drive more customers to purchase the product (Anwar and Sofyan, 2011). Previous study by Forsido (2012) also stated that, brand image that are favourable would have a positive impact on consumer behaviour towards the brand in which it leadto loyalty. Current study also discovers that trust influence brand loyalty for smartphone users among Generation Y, which also in line with Reichheld \& Schefter (2000). Trust is one of the most important factors that lead to brand loyalty. Current findings also showed that customer satisfaction influence brand loyalty among Smartphone user in line with previous findings by Li and Chaipoopirutana, (2014). There are several literature stated that satisfaction was integrated as a dominant factor which leads to brand loyalty. It is found that customer satisfaction improves reputation in services markets and reputation intervene the relationship of customer satisfaction and brand loyalty (Farhanullah and Adeeba, 2013). In this study, it can be confirmed that Generation Y were satisfied with their smartphone brand that have been currently used. According to Dick and 
Basu (1994), a satisfied customer would recommend a brand to his or her friend and that would lead to brand loyalty. A good promotion could attract many consumers to purchase their brand as the promotion that they offer was a great offer where it gives specialty to the consumer. However, current study showed that, the promotion has no significantrelationship with brand loyalty. These findings, however, conflict with previous studies. It is believed that the difference of this findings is because of Generation $Y^{\prime} s$ lifestyle.Generation $Y$ isa generation of millennial and they are exposed widely to technology and social media (Marmaya et al., 2019), so by using expensive smartphone makes them feel famous and stylish and may put them popularin social media. Even other brand makes a lot of effort on to carried on a lot of promotion deals with their target consumer to compete with other global brand, even the other global brand makes a huge promotion, and they still stick on the first choice of the global brand of Smartphone. This can be seen through brand of Apple, where Apple rarely makes promotion compare with other brand of Smartphone but still become one of the first choice among Generation Y.The empirical findings of this study validates that brand image, trust and customer satisfaction predict consumers' brand loyalty and our results show that $51 \%$ variance of brand loyalty is explained. The higher the value and identification consumers perceive, the greater commitment to repurchase and recommend a given brand will be. This finding implies that smartphone brand loyalty may primarily depend on individual factors rather than interpersonal factors. Given that brand image, trust and satisfaction value contribute to brand loyalty, smartphone marketers should also establish brand identity in terms of functional value, emotional value, social value, and brand identification ( $\mathrm{CH}$ Yeh, YS Wang, K Yieh, 2016). Some limitations should be acknowledged. First, the data collection for current study is confined to respondents from Malaysia that indicates the generalisation issue. Future research should attempt to reach larger groups of respondents to validate the theoretical linkage tested in the present study. Secondly, this results in a relatively small size (152), compared with the population size. This also might affect the representative of the outcomes. There are several more suggestions to further extend the current model. First, the research model can be tested in different group of customer and investigates if people with different background may assess different brand loyalty to buy smartphone in different ways. Longitudinal research design should be done for a better result.

\section{Practical Implications}

This study was developed to identifying the important factors which affect customer loyalty in the mobile phone industry. As we can see that there is a number of brands in market and marketers find intense competition, so this study will help marketers and manufacturers to make marketing strategies and will help to make commercial decisions. The data which was gathered under the umbrella of four essential variables will help marketers to make a decision that at what variable they have to focus like making a brand image, building trust, go for promotion or to get customer satisfied by focusing on product quality. In this study all variables suggested the positive relationship between independent variables and dependent variable except promotion, there is a reason behind those local markets and are not observing any promotion of international brands through electronic media. 


\section{Practical Implications}

This study was developed to identifying the important factors which affect customer loyalty in the mobile phone industry. As we can see that there is a number of brands in market and marketers find intense competition, so this study will help marketers and manufacturers to make marketing strategies and will help to make commercial decisions. The data which was gathered under the umbrella of four essential variables will help marketers to make a decision that at what variable they have to focus like making a brand image, building trust, go for promotion or to get customer satisfied by focusing on product quality. In this study all variables suggested the positive relationship between independent variables and dependent variable except promotion, there is a reason behind those local markets and are not observing any promotion of international brands through electronic media.

\section{Practical Implications}

This study was developed to identifying the important factors which affect brand loyalty in the mobile phone industry among generation Y. Findings of this study will help marketers and manufacturers to make marketing strategies and will help to make the best commercial decisions to increase their sales. This study also will help marketers to make a decision on what factors they need to focus to get customer satisfaction.

\section{References}

Anderson, R. E. and Srinivasan, S. S. (2003) E-satisfaction and e-loyalty: A contingency framework. Psychology and Marketing, 20(2), 123-138

Andreani, F., Taniaji, T. L., Puspitasari, R. N. M. (2012), The impact of brand image towards loyalty with satisfaction as a mediator in Mcdonald's. Journal Manajemen dan Kewirausahaan, 14(1), 64-71.

Anderson, J. C., Gerbing, D. W., \& Hunter, J. E. (1987). On the Assessment of Unidimensional Measurement: Internal and External Consistency, and Overall Consistency Criteria. Journal of Marketing Research, 24, 432-437.

Anwar, T. A. \& Sofyan, R. (2011). The influence of brand image and customer value on customer loyalty of Nokia high-end in Bandung. International Seminar on Business and Management: Improving Business Competiveness Through Integrated System, Bandung, Indonesia

Bontis, N., and Serenko, A. (2007), "The moderating role of human capital management practices on employee capabilities", Journal of Knowledge Management, Vol. 11 No. 3, pp. 31-51.

Chang, C. H., Tu, C. Y. (2005). Exploring store image, customer satisfaction and customer loyalty relationship: evidence from Taiwanese hypermarket industry. J. Am. Acad. Bus., 7(2): 197-202.

Chaudhuri, A., Holbrook, M. B. (2001). The chain of effects from brand trust and brand affect to brand performance: The role of brand loyalty. J. Mark., 65(2): 81-94

Chen, C. C., Chen, X. P., \& Huang, S. (2013). Guanxi and social network research: Review and future directions. Management and Organization Review, 9(1), 167-207. https://doi.org/10.1111/more.12010 
Czerniawski, Richard, D., and Michael, W. Maloney. Creating Brand Loyalty: The Management of Power Positioning and Really Great Advertising (1999) (ch. 2, 6, 7, 8, 12). Broadway: AMA Publications, 1999. Print

Deari, H., and Balla, E. (2013). Consumers trust in the global brands: empirical analysis in the context of consumer perspective. European Scientific Journal, vol.9, No.1, January, pp. 61-74.

Dick, A. S. \& Basu, K. (1994). Customer loyalty: Toward and integrated conceptual framework. Journal of the Academy of Marketing Science, 22(2), 99-113.

Dosstdar. (2013). The Impact of Mobile Phone Brands on Customer Satisfaction and Loyalty. International Research Journal of Applied and Basic Sciences, 5 (8), 957-961.

Esfahani, N. A. \& Jafarzadeh, M. (2012). Studying impacts of sales promotion on consumer's psychographic variables. Interdisciplinary Journal of Contemporary Research in Business, 3(9), 1278-1288.

Evans, K., Christiansen, T., \& Gill, J. D. (1996). The impact of social influence and role expectations on shopping center patronage intentions. Academy of Marketing Science Journal, 24(3), 208-218.

Farhanullah, S., and Adeeba, A. (2013) Factors Affecting Brand Loyalty in Pakistan-Brand Loyalty of Apple Iphone in Pakistan. KASBIT, Karachi

Forsido, M. (2012). Brand loyalty in Smartphone. (Master of Science), Uppsala Universitet.

Gerbing, D. W., \& Anderson, J. C. (1988). An updated paradigm for scale development incorporating unidimensionality and its assessment. Journal of Marketing Research, 25, 186-192

Greenwood, M., \& Buren, V. III, H. J. (2010). Trust and stakeholdertheory: Trustworthiness in the organization-stakeholder relationship. Journal of Business Ethics, 95, 425-438

Greenwood, M., \& Buren, V. III, H. J. (2010). Trust and stakeholder theory: Trustworthiness in the organization-stakeholder relationship. Journal of Business Ethics, 95, 425-438

Kahn, B. E., and Therese, A. L. (1990), "The Effects of Retraction of Price Promotions on Brand Choice Behavior for Variety-Seeking and Last-Purchase Loyal Customers," Journal of Marketing Research, XXVII (August), 279-289.

Kansra \& Kumar. (2012), Brand Relationship and Switching Behavior for Mobilephone in Young Consumers in Punjab, South Asian Academic Research Journal, Vol 2, Issue 2

Khundyz, Z. (2018) The Influence Factors of Brand Loyalty: Mobile Phone Industry. American Journal of Industrial and Business Management, 8, 1624-1633

Kinuthia, L. N., Mburugu, K. G., Muthomi, H. N., \& Mwihaki, M. (2012). Factors influencing brand loyalty in sportwear among Kenyan University students: The case of swimmers. Asian Journal of Social Sciences Humanities, 1(4), 223-231.

Koo, D. M. (2003). Inter-relationships among store images, store satisfaction, and store loyalty among Korea discount retail patrons. Asia Pacific Journal of Marketing and Logistics, 15(4), 42-71.

Kuusik, A. (2007), “Affecting Customer Loyalty: Do Different Factors Have Varius Influences in Different Loyalty Levels, ISBN 978,9949, 11-735

LaBarbera, P. A. \& Mazursky, D., (1983), A Longitudinal Assessment of Consumer Satisfaction, Dissatisfaction: the Dynamic Aspect of Cognitive Process, Journal of Marketing Research, Vol. 20, November, pp. 393-404.

Ling, L., Goyindan, S. \& Radhakrishnan, R. (2018). Consumer Brand switching Behavior: Evidence From Malaysian Smartphone User. E-Academia Journal, 7(2), 20-30. 
Li, Z., \& Chaipoopirutana, A. P. D. S. (2014). THE IMPORTANT FACTORS THAT INFLUENCE ON BUILDING BRAND LOYALTY TOWARDS CHANG'AN CAR BRAND IN XI'AN CITY, SHAANXI, CHINA. Retrieved from

http://utcc2.utcc.ac.th/utccijbe/_uploads/InProcess/201412/THE\%20IMPORTA T\%20FACTORS\%20THAT\%2OINFLUENCE\%200N\%20BUILDING\%20BR ND\%20LOYALTY\%20TOWARDS\%20CHANG.pdf

Chaipoopirutana, S., Intravisit, A. \& Dauch. (2016). The Influencing Factors toward Brand Loyalty ofSmartphone in Phnom Penh, Cambodia. RSU International Research Conference.

Malik, M. E., Ghafoor, M. M., \& Iqbal, H. K. (2012). Impact of brand image, service quality and price on customer satisfaction in Pakistan telecommunication sector. International Journal of Business and Social Science, 3(23), 123-129.

Marmaya, N. H., Zakaria, Z., MohdDesa, M. N. (2019) "Gen Y consumers' intention to purchase halal food in Malaysia: a PLS-SEM approach", Journal of Islamic Marketing, https://doi.org/10.1108/JIMA-08-2018-0136

Martenson, R. (2007). Corporate brand image, satisfaction and store loyalty. International Journal of Retail \& Distribution Management, 35(7), 544-555.

Mise, J. K., Nair, C. Odera, O., \& Ogutu, M. (2013). Comparative Study on Brand Loyalty in Kenya and India Consumer of Softdrinks Market. Global Journal of Management and Business Research Marketing, 13(3).

Ramiz, M., Qasim, M., Rizwan, M., Aslam, F., \& Khurshid, A. (2014) The Comparative Analysis of the Factors Effecting Brand Loyalty towards Samsung Products. Journal of Sociological Research, 5(1), 327-349.

Raval, R. \& Trivedi, R. (2018). Consumer Purchase Intentions towards Smartphone: A Factorial Study. International Journal of Advance Research in Computer Science and Management Studies, 6(4), 40-48.

Reichheld, F. F., and Schefter, P. (2000). E-loyalty:Your secret weapon on the Web. Harvard Business Review, 78, 105-113

Ronaldo, W,. and Atik, A. (2015) Factors Influencing Brand Loyalty towards Sportswear in Bandung. Journal of Business and Management, 4, No. 8.

Ross, B. (2014). "Why Customer Satisfaction is Important". Retrieved from http://blog.clientheartbeat.com/whycustomer-satisfaction-is-important/.

Singh, R. (2016) Factors Affecting Brand Loyalty in The Footwear Industry-A Study Of Ludhiana District. International Journal of Research, 4, 139-149.

Sun, B. (2005). Promotion effect on endogenous consumption. Marketing science, 24(3), 430443.

Tee, B. \& Benjamin. (2013) Malaysian Young Consumer Preferences In Choosing International Fashion Brand, Journal of Human and Social Science Research Vol. 1, No. 1, 31-38

Lin, T. Y. and Chang, M. Y. (2013). A study of the factors that influence the brand loyalty of Taiwanese adolescents with respect to purchasing mobile. The case of Taichung City. Problems and Perspectives in Management, 11(2)

Wong, F. Y., and Sidek, Y. (2008). Influence of brand loyalty on consumer sportswear. International Journal of Economics and Management, 2 (2). pp. 221-236. ISSN 1823-836X 
INTERNATIONAL JOURNAL OF ACADEMIC RESEARCH IN BUSINESS AND SOCIAL SCIENCES

Vol. 9, No. 10, October, 2019, E-ISSN: 2222-6990 @ 2019 HRMARS

\section{Corresponding Author}

Dr. Najihah Hanisah bte Marmaya, UiTM Cawangan Melaka, Kampus Bandaraya Melaka, 110 Off Jalan Hang Tuah, 75300 Melaka, Malaysia

Email: najihah_02@yahoo.com 